\title{
Pengembangan Lembar Kerja Peserta Didik Berbasis Realistic Mathematics Education untuk Meningkatkan Kemampuan Argumentasi Peserta Didik
}

\author{
Fera Zulainy ${ }^{1}$, Rusdi ${ }^{2}$, Jefri Marzal ${ }^{3}$ \\ 1,2,3Program Studi Magister Pendidikan Matematika, Universitas Jambi. Jalan Raden Mataher No. 16 - Jambi. \\ myhubbyldw@gmail.com
}

\begin{abstract}
Students of XII IPA MAN 5 Batanghari have not been trained to argue. This is based on the facts obtained at the time of observation during the learning process that only a few students are seen to submit opinions regarding the subject matter. When the teacher gives questions, students answer only in the form of simple statements without supporting either evidence or reasons. The low attainment of the ability to argue is thought to be related to the learning process which has not fully practiced these abilities. One of the innovations and alternatives in learning mathematics so that the argumentation skills of student increase is the development of teaching materials in the form of Student Worksheets. This development research aims to (1) find out the recommended procedures for designing and developing products; (2) knowing the conditions conducive to designing and developing products efficiently; and (3) knowing the potential impact that can be described by the product to improve students' argumentative skills. The development model used is the ADDIE model with the Analyze, Design and Development stages. The development model used is the ADDIE model with the Analyze, Design and Development. Based on this research, it was found that the recommended procedures and conditions were conducive to designing and developing LKPD based on Realistic Mathematics Education. The application of learning and learning theory and the principles of RME have been well embedded in the product and declared valid by the validator. The application of these theories has a logical impact or implication on the argumentation component so that it can be concluded that student worksheets based on RME have the potential to improve students' argumentation skills.
\end{abstract}

Keywords: Student Worksheets, Realistic Mathematics Education, Argumentation

\begin{abstract}
Abstrak
Peserta didik kelas XI MIPA MAN 5 Batang Hari belum terlatih berargumentasi. Hal ini didasarkan oleh fakta yang didapat pada saat observasi selama proses pembelajaran bahwa hanya sedikit peserta didik yang terlihat mengajukan pendapat terkait materi. Ketika guru memberikan pertanyaan, peserta didik menjawab hanya berupa pernyataan sederhana tanpa disertai pendukung baik itu berupa bukti maupun alasan. Rendahnya pencapaian pada kemampuan berargumentasi diduga terkait dengan proses pembelajaran yang belum sepenuhnya melatihkan kemampuan-kemampuan tersebut. Salah satu inovasi dan alternatif dalam pembelajaran matematika agar kemampuan argumentasi peserta didik meningkat yaitu dengan pengembangan bahan ajar berupa Lembar Kerja Peserta Didik (LKPD). Penelitian pengembangan ini bertujuan untuk (1) mengetahui prosedur yang direkomendasikan dalam mendesain dan mengembangkan produk; (2) mengetahui kondisi yang kondusif untuk mendesain dan mengembangkan produk secara efisien; dan (3) mengetahui potensi dampak yang dapat dideskripsikan oleh produk untuk meningkatkan kemampuan argumentasi peserta didik. Model pengembangan yang digunakan adalah model ADDIE dengan tahapan Analyze, Design dan Development. Berdasarkan penelitian ini didapatkan prosedur yang direkomendasikan serta kondisi yang kondusif dalam mendesain dan mengembangkan LKPD berbasis Realistic Mathematics Education. Penerapan teori belajar dan pembelajaran serta prinsip RME sudah tertanam dengan baik pada produk dan dinyatakan valid oleh validator. Penerapan teori-teori ini memberikan dampak atau implikasi secara logis pada komponen argumentasi sehingga dapat disimpulkan bahwa lembar kerja peserta didik berbasis RME berpotensi meningkatkan kemampuan argumentasi peserta didik. Kata kunci: Lembar Kerja Peserta Didik, Realistic Mathematics Education, Argumentasi
\end{abstract}

Copyright (c) 2021 Fera Zulainy, Rusdi, Jefri Marzal

$\triangle$ Corresponding author: Fera Zulainy

Email Address: myhubbyldw@ gmail.com (Jalan Raden Mataher No. 16 - Jambi)

Received 04 Januari 2021, Accepted 08 Maret 2021, Published 30 Maret 2021

\section{PENDAHULUAN}

Proses pembelajaran pada kurikulum 2013 merupakan proses pembelajaran yang berpusat pada peserta didik dan bersifat kontekstual. Hal ini mengakibatkan peserta didik dituntut untuk mampu dalam 
mengedepankan pengalaman personalnya melalui kegiatan observasi (menyimak, melihat, membaca dan mendengar), asosiasi, bertanya, menyimpulkan serta mengkomunikasikan. Selain itu, salah satu tujuan pembelajaran matematika dari segi kompetensi keterampilan adalah peserta didik mampu menunjukkan keterampilan menalar, mengolah, dan menyaji secara kreatif, produktif, kritis, mandiri, kolaboratif dan komunikatif (Kemendikbud, 2016).

Menalar adalah berpikir logik, mengaitkan konsep dan fakta, mengaitkan keterhubungan faktafakta dan mencari apakah ada sebab akibat antarfakta, baik linier maupun bertolak belakang. Secara umum, penalaran dapat dikatakan sebagai proses penarikan kesimpulan berdasarkan bukti-bukti atau asumsi yang ada. Kemampuan menalar ini diperlukan oleh peserta didik untuk memahami fakta-fakta dan menjelaskan fenomena ilmiah yang ada di dalamnya. Ketika peserta didik bernalar maka mereka akan mengembangkan argumen-argumen untuk meyakinkan orang lain atau diri mereka sendiri dari klaim tertentu; untuk memecahkan masalah atau untuk mengintegrasikan sejumlah gagasan menjadi satu kesatuan yang lebih koheren (Umah et al., 2016). Dengan demikian penggunaan argumentasi dalam pembelajaran merupakan bagian dari pengembangan kemampuan menalar peserta didik.

Kemampuan argumentasi adalah kemampuan peserta didik dalam menarik kesimpulan berdasarkan fakta atau informasi yang ada. Berdasarkan model argumentasi Toulmin, komponen argumentasi terdiri dari enam elemen yaitu claim, data, warrant, qualifier, rebuttal, dan backing. Keenam komponen inilah yang akan dijadikan sebagai indikator kemampuan argumentasi peserta didik. Kemampuan argumentasi peserta didik dikatakan baik jika memuat keenam komponen argumentasi tersebut.

Selain itu, kegiatan berargumentasi juga diberikan dengan maksud untuk dapat meningkatkan kemampuan berpikir kritis peserta didik. Kemampuan argumentasi memiliki peranan penting dalam mengembangkan pola berpikir kritis peserta didik serta menambah pemahaman peserta didik terhadap suatu gagasan ataupun ide (Deane \& Song, 2014). Dengan kemampuan argumentasi diharapkan peserta didik dapat melakukan proses berpikir serta berinteraksi dalam membangun dan mengevaluasi argumen lain (Amielia et al., 2018). Selain itu, berdasarkan hasil penelitian, kemampuan argumentasi peserta didik dapat ditingkatkan dengan memasukkan praktik argumentasi ke dalam kurikulum (Acar \& Patton, 2012).

MAN 5 Batanghari adalah salah satu sekolah yang menerapkan kurikulum 2013. Berdasarkan fakta terhadap observasi awal selama proses pembelajaran di kelas XI MIA MAN 5 Batanghari hanya sedikit peserta didik yang terlihat mengajukan pendapat terkait materi. Ketika guru memberikan pertanyaan, peserta didik menjawab hanya berupa pernyataan sederhana tanpa disertai pendukung baik itu berupa bukti maupun alasan. Interaksi antara peserta didik dengan peserta didik maupun guru juga terlihat kurang intensif. Fakta ini mengidentifikasikan bahwa peserta didik belum terlatih berargumentasi. Hal ini dikarenakan guru belum menerapkan model pembelajaran yang dapat membuat peserta didik aktif dalam berargumen selama proses pembelajaran. Rendahnya pencapaian pada kemampuan berargumentasi diduga terkait dengan proses pembelajaran yang belum sepenuhnya 
melatihkan kemam $\neg$ puan-kemampuan tersebut. Untuk mengatasi masa $\neg$ lah tersebut diperlukan suatu inovasi pembelajaran yang dapat bermakna bagi peserta didik, serta dapat melatihkan dan meningkatkan kemampuan berargumentasi peserta didik. Salah satu inovasi dan alternatif dalam pembelajaran matematika agar kemampuan argumentasi peserta didik meningkat yaitu dengan pengembangan bahan ajar berupa Lembar Kerja Peserta Didik (LKPD).

LKPD yang dikembangkan berbasis Realistic Mathematics Education. Realistic Mathematics Education merupakan pembelajaran matematika yang memberikan peserta didik kesempatan untuk menemukan kembali dan memahami konsep-konsep matematika berdasarkan pada masalah realistik yang diberikan oleh guru. Realistic Mathematics Education terdiri dari 5 langkah kegiatan yaitu memahami masalah kontekstual, menjelaskan masalah kontekstual, menyelesaikan masalah kontekstual, membandingkan dan mendiskusikan jawaban dan menyimpulkan (Ningsih, 2014). Dalam RME, peserta didik sebagai subjek belajar akan dituntut untuk dapat memberikan kontribusinya dalam kegiatan belajar, yang meliputi ide, gagasan maupun argumen tentang konsep matematika. Setiap langkah dalam RME ini mampu mengakomodasi kemampuan argumentasi peserta didik sehingga diharapkan melalui penggunaan model Realistic Mathematics Education, kemampuan berargumentasi peserta didik menjadi lebih meningkat. Berdasarkan uraian diatas, maka peneliti bermaksud untuk melaksanakan penelitian dengan judul "Pengembangan Lembar Kerja Peserta Didik Berbasis Realistic Mathematics Education untuk Meningkatkan Kemampuan Argumentasi Peserta didik".

\section{Realistic Mathematics Education (RME).}

Realistic Mathematics Education (RME) atau yang berarti Pembelajaran Matematika Realistik (PMR) adalah salah satu teori pembelajaran dalam bidang matematika. RME ini dikembangkan atas dasar gagasan dari Hans Frudenthal yang menyatakan bahwa matematika merupakan suatu kegiatan manusia (Isrok'atun \& Rosmala, 2018). Lebih lanjut, Freudenthal (Wijaya, 2012) menyatakan bahwa matematika yang baik yaitu matematika yang tidak diberikan secara langsung kepada peserta didik sebagai sebuah produk jadi melainkan sebagai suatu bentuk kegiatan dimana konsep matematika dapat dikontruksi. Tarigan (Bunga et al., 2017) berpendapat bahwa Realistic Mathematics Education memiliki tujuan dalam mengembangkan pola pikir praktis, logis, kritis, dan jujur dengan orientasi pada penalaran matematika dalam penyelesaian masalah.

(Bunga et al., 2017) menyatakan bahwa pembelajaran matematika realistik menggunakan konteks dunia nyata sebagai topik pembelajaran. Senada dengan pendapat tersebut Slettenhar (Ningsih, 2014) juga mengemukakan bahwa realistik tidak hanya mengacu pada realitas tetapi juga pada sesuatu yang dapat dibayangkan peserta didik. Hal ini berarti pembelajaran matematika diterapkan melalui peristiwa nyata dalam kehidupan yang dekat dengan pengalaman anak dan berhubungan dengan masyarakat sehingga dapat dibayangkan oleh peserta didik. Selanjutnya ilmu matematika diperoleh peserta didik dari mengkontruksi secara mandiri konsep berdasarkan peristiwa nyata yang dapat dibayangkan oleh peserta didik. Selain itu, dalam pembelajarannya, model RME membuat pembelajaran lebih bermakna karena menuntut peserta didik untuk membangun pengetahuannya sendiri (Bunga et al., 2017). 
Menurut Treffers (Wijaya, 2012) model realistic mathematics education memiliki lima karakteristik yakni: 1) penggunaan konteks, 2) pengunaan model untuk matematisasi progresif, 3) pemanfaatan hasil konstruksi peserta didik, 4) interaktivitas dan 5) keterkaitan. Selain karakteristik, model realistic mathematics education juga memiliki prinsip. (Gravemeijer, 1994) mengemukan tiga prinsip RME, yaitu: 1) penemuan kembali secara terbimbing melalui matematisasi progresif (guided reinvention through progressive mathematizing), 2) fenomena diktatik (didactical phenomenology) dan 3) pengembangan model mandiri (self developed models).

Model Realistic Mathematics Education memiliki langkah-langkah atau sintak pembelajaran yang berfungsi sebagai cara agar peserta didik memahami konsep matematika secara utuh dan bermakna. Menurut Hobri (Ningsih, 2014) terdapat lima langkah dalam RME, yaitu: 1) memahami masalah kontekstual, 2) menjelaskan masalah kontekstual, 3) menyelesaikan masalah kontekstual, 4) membandingkan dan mendiskusikan jawaban dan 5) menyimpulkan.

\section{Lembar Kerja Peserta Didik (LKPD)}

Menurut (Prastowo, 2015), LKPD merupakan suatu bahan ajar cetak yang terdiri dari lembaranlembaran kertas yang berisi materi, ringkasan, dan petunjuk-petunjuk pelaksanaan tugas pembelajaran yang harus dikerjakan oleh peserta didik berdasarkan kompetensi dasar yang ingin dicapai. (Prastowo, 2015) berpendapat bahwa LKPD terdiri dari enam unsur utama yaitu judul, petunjuk belajar, kompetensi dasar atau materi pokok, informasi pendukung, tugas atau langkah-langkah kerja dan penilaian.

Menurut Diknas dalam (Prastowo, 2015), langkah-langkah dalam menyusun LKPD, yaitu : (1) Melakukan analisis kurikulum dengan cara melihat materi pokok, pengalaman belajar, kompetensi yang harus dimiliki peserta didik dan materi yang akan diajarkan; (2) Membuat peta kebutuhan LKPD; (3) Menentukan judul LKPD berdasarkan kompetensi dasar, materi pokok atau pengalaman belajar yang ada dalam kurikulum; dan (4) Penulisan LKPD dengan langkah-langkah : merumuskan kompetensi dasar, menentukan alat penilaian, menyusun materi, dan memperhatikan struktur LKPD. Sedangkan langkah-langkah dalam mengembangkan LKPD, yaitu: (1) Menentukan tujuan pembelajaran; (2) Mengumpulkan materi; (3) Menyusun elemen atau unsur-unsur LKPD; dan (4) Melakukan pemeriksaan dan penyempurnaan. Bagian akhir dari pengembangan LKPD adalah melakukan evaluasi terhadap LKPD tersebut. Evaluasi ini bertujuan untuk mengetahui apakah LKPD yang dikembangkan telah baik ataukah masih ada yang perlu diperbaiki.

\section{Kemampuan Argumentasi}

Menurut (KBBI, 2020), argumen adalah alasan yang dapat dipakai untuk memperkuat atau menolak suatu pendapat, pendirian, atau gagasan. Sedangkan Means \& Voss (Dawson \& Venville, 2010) menggambarkan argumen sebagai pendapat dari suatu kesimpulan yang didukung oleh minimal satu alasan. Penyampaian atau penerapan dari argumen-argumen tersebut disebut dengan argumentasi.

Argumentasi adalah proses memperkuat suatu klaim dengan cara berpikir kritis berdasarkan dengan bukti-bukti dan alasan yang logis (Ginanjar et al., 2015). Sedangkan (Hendri \& Defianti, 2015) mengemukakan bahwa argumentasi adalah proses membuat pernyatan dan memperoleh justifikasi dari 
pernyataan tersebut disertai dengan bukti-bukti yang logis. Bukti-bukti ini dapat berupa fakta atau kondisi objektif yang dapat diterima kebenarannya. Dengan demikian, argumentasi dapat melatih peserta didik dalam menggunakan kemampuan berpikirnya. Hal ini sesuai dengan pendapat (Deane \& Song, 2014) yang menyatakan bahwa argumentasi memiliki peranan penting dalam mengembangkan pola pikir kritis dan pemahaman yang mendalam terhadap suatu masalah atau ide yang kompleks.

Secara umum, argumentasi harus dipahami sebagai aktivitas metacommunicative yang berarti sesuatu yang dapat menghasilkan ketika keyakianan akan tindakan sehari-hari diragukan. Oleh karena itulah konsep argumentasi ini sangat tepat digunakan untuk menjelaskan aspek-aspek spesifik dari aktivitas sehari-hari (Aberdein \& Dove, 2013). Dalam kasus matematika, sifat argumentatif ini dapat kita jumpai pada proses pemecahan masalah serta dalam mengikuti metode penalaran untuk mencapai sebuah solusi tertentu.

Menurut Toulmin (Eemeren et al., 2014), indikator argumentasi terdiri dari enam elemen, yaitu claim, data, warrant, qualifier, rebuttal, dan backing. Claim (C) adalah pernyataan yang diharapkan oleh pemberi argumen dapat menyakinkan orang lain. Claim juga dapat dikatakan sebagai pernyataan atau kesimpulan yang didasarkan oleh data (Laamena, 2017). Menurut (Brinkerhoff, 2007), argumen diberikan untuk membuktikan kebenaran dari suatu claim. Data (D) adalah dasar dari argumen atau merupakan bukti yang relevan untuk claim. Lebih lanjut Toulmin (Brinkerhoff, 2007) menjelaskan bahwa data adalah segala sesuatu yang dapat diterima tanpa pertanyaan. Warrant (W) adalah pernyataan yang menunjukkan bagaimana data terkait dengan claim (Brinkerhoff, 2007). Sementara menurut (Laamena, 2017), warrant bisa saja menyatakan suatu aturan, definisi atau membuat suatu analogi.

Elemen yang keempat yaitu Backing (B) adalah sesuatu yang menghadirkan bukti lebih jauh yang dapat mendukung warrant. Sedangkan elemen terakhir dari model argumentasi Toulmin adalah Qualifier (Q). Qualifier (Q) mengkualifikasi kesimpulan dengan mengekspresikan derajat keyakinan dan Rebuttal (R) adalah sesuatu yang dapat menolak kesimpulan dengan menyatakan kondisi dimana kesimpulan tersebut tidak berlaku (Umah et al., 2016).

\section{METODE}

Prosedur pelaksanaan penelitian pengembangan yang akan dilakukan pada penelitian ini menggunakan model ADDIE yang terdiri dari tahap analysis (analisis), design (perancangan), development (pengembangan), implementation (implementasi), dan evaluation (evaluasi). ADDIE adalah konsep pengembangan produk yang memiliki tujuan untuk membangun pembelajaran berbasis kinerja (Branch, 2009). Kerangka ADDIE merupakan kerangka yang paling populer dalam mendesain dan mengembangkan produk baik untuk tipe aliran berpikir analitis maupun ilmiah. Hal ini dikarenakan kerangka ADDIE memiliki kerangka kerja yang runut dan sistematis dalam mengorganisasikan rangkaian kegiatan dalam penelitian pengembangan (Rusdi, 2019). Pada penelitian pengembangan ini, peneliti hanya akan memakai tiga tahapan dalam kerangka ADDIE yaitu 1) tahap analysis (analisis) yang terdiri dari analisis kebutuhan kurikulum, analisis karakteristik peserta didik dan analisis 
lingkungan belajar, 2) tahap design (perancangan) yang terdiri dari penentuan tim pengembang, penyususnan jadwal pengembangan, menentukan struktur materi, pembuatan storyboard, menentukan spesifikasi produk, dan membuat prototype produk, dan 3) tahap development (pengembangan) yang terdiri dari validasi ahli dan praktisi. Hal ini karenakan kondisi pembelajaran saat ini yang tidak memungkinkan peneliti untuk melaksanakan uji coba langsung kepada peserta didik dikarenakan wabah COVID-19 yang sedang melanda.

Jenis data dalam penelitian ini adalah data kualitatif yang diperoleh dari angket validasi ahli materi, ahli desain pembelajaran, ahli desain produk dan praktisi yang dalam hal ini dilakukan oleh 2 oran guru matematika serta catatan harian peneliti. Instrumen yang digunakan dalam penelitian ini adalah angket terbuka yang diberikan kepada validator ahli dan praktisi serta daily log. Angket terbuka digunakan untuk mendapatkan data yang dibutuhkan dalam menjawab rumusan masalah pertama dan ketiga. Sedangkan daily log digunakan untuk menjawab rumusan masalah kedua. Metode pengumpulan data pada penelitian ini dilakukan dengan cara analisis dokumen, melakukan survey dan mencatat aktivitas harian. Teknik analisis data yang dipakai pada penelitian pengembangan ini adalah analisis data kualitatif. Analisis data kualitatif dilakukan selama proses penelitian sedang berlangsung. Teknik analisis data yang digunakan dalam penelitian ini adalah teknik spiral.

\section{HASIL}

\section{Prosedur Pengembangan LKPD}

Dalam pengembangan LKPD ini menggunakan model ADDIE yang terdiri dari tiga tahapan yaitu analyze, design, dan development.

Analyze

Tahap analisis terdiri dari analisis kebutuhan kurikulum, analisis karakteristik peserta didik, dan analisis lingkungan belajar. Tahap analisis kurikulum dilakukan dengan mengumpulkan dokumendokumen yang berkaitan dengan pengembangan kurikulum. MAN 5 Batang Hari menggunakan kurikulum 2013. Hasil dari analisis kurikulum berupa kompetensi dasar, serta indikator pembelajaran yang digunakan sebagai pedoman penyusunan materi Barisan pada LKPD.

Tahap analisis karakteristik peserta didik dan lingkungan belajar dilakukan dengan memberikan angket terbuka dalam bentuk google form. Masing-masing angket terbuka terdiri dari 6 pertanyaan berkaitan dengan tingkat usia, sikap belajar, minat belajar, gaya belajar, motivasi dan persepsi peserta didik terhadap mata pelajaran matematika serta 12 pertanyaan terkait suasana belajar dikelas, pola interaksi guru dan peserta didik dan antar peserta didik, potensi keterlibatan peserta didik dalam proses belajar serta ketersediaan sumber belajar. Berdasarkan angket analisis karakteristik peserta didik terhadap 28 peserta didik, didapat bahwa peserta didik kelas XI MIPA berada pada kisaran umur 15 17 tahun, sebagian besar peserta didik memperhatikan penjelasan guru dan memiliki minat belajar terhadap mata pelajaran matematika, 19 peserta didik memiliki gaya belajar kinestetik, 7 peserta didik memiliki gaya belajar visual dan 2 peserta didik memiliki gaya belajar auditori. Lebih lanjut, sebagian 
besar peserta didik memiliki persepsi bahwa matematika merupakan pelajaran yang sulit. Akan tetapi mereka tetap memiliki motivasi dalam belajar matematika agar mendapatkan ilmu yang berguna bagi masa mendatang.

Pada tahap analisis lingkungan belajar, hasil angket menunjukkan bahwa peserta didik merasa suasana belajar di kelas menyenangkan, tidak membosankan dan nyaman. Hal ini dikarenakan kondisi kelas yang kondusif selama pembelajaran berlangsung serta kondisi fisik kelas yang cukup baik. Interaksi yang terjadi didalam kelas baik antara guru dan peserta didik maupun antar peserta didik juga terjadi dengan baik. Dalam hal keterlibatan peserta didik dalam pembelajaran, 18 peserta didik menjawab bahwa mereka tidak aktif dalam pembelajaran. Hasil lainnya terkait sumber belajar yang digunakan oleh peserta didik adalah penggunaan buku dan internet sebagai sumber belajar.

Design

Tahap selanjutnya adalah tahap design merupakan tahapan dimulainya rancangan LKPD yang akan dikembangkan sesuai dengan hasil analisis yang telah dilakukan. Langkah-langkah yang dilakukan peneliti pada tahap design ini adalah menentukan tim pengembang, menyusun jadwal pengembangan, menentukan struktur materi, membuat storyboard, menentukan spesifikasi produk dan membuat prototipe produk. Pada tahapan ini dihasilkan sebuah prototype LKPD berbasis realistic mathematics education untuk meningkatkan kemampuan argumentasi peserta didik. Adapun prototype dari LKPD ini tersusun atas beberapa bagian yaitu halaman sampul, halaman pendahuluan dengan menggunakan penomoran angka romawi yang terdiri dari kata pengantar, petunjuk penggunaan LKPD, daftar isi. Halaman isi yang terdiri dari cover materi, peta konsep, kompetensi inti dan kompetensi dasar yang ingin dicapai oleh peserta didik, indikator dan tujuan pembelajaran, materi, latihan, uji kemampuan dan halaman penutup berisi daftar referensi. Materi dan latihan didesain sesuai dengan RPP yang telah dibuat sebelumnya. LKPD didesain menggunakan software Microsoft word untuk memfasilitasi pengeditan teks dan gambar. Ukuran kertas menggunakan ukuran A4 $(21 \mathrm{~cm}$ x 29,7 cm) dengan ketebalan 80 gr. Desain LKPD didominasi dengan warna biru. Desain sampul depan dilengkapi dengan gambar bakteri yang berkaitan dengan materi yang dipelajari terkait pertumbuhan. Jenis huruf yang digunakan ada dua yaitu Broadway dan Berlin Sans FB. Tampilan halaman LKPD dibuat semenarik mungkin agar peserta didik tertarik dalam menggunakan LKPD.

Adapun bentuk dari prototipe LKPD dapat dilihat pada gambar dibawah ini: 
Pengembangan Lembar Kerja Peserta Didik Berbasis Realistic Mathematics Education untuk Meningkatkan Kemampuan Argumentasi Peserta Didik, Fera Zulainy, Rusdi, Jefri Marzal

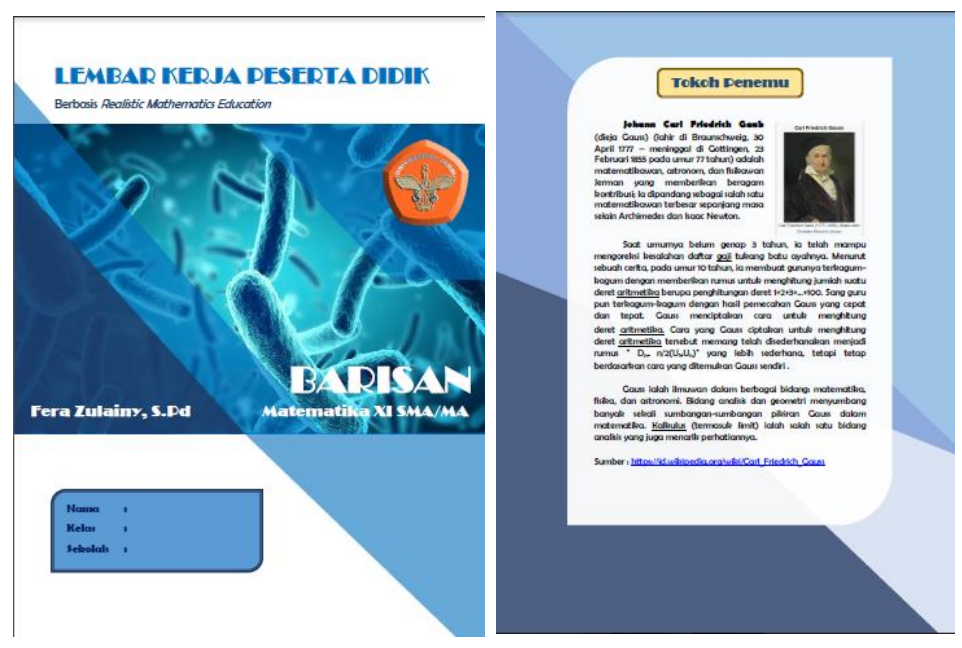

(a)

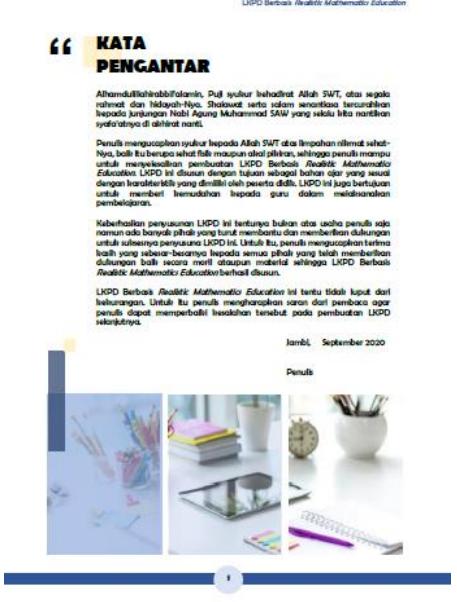

(b)

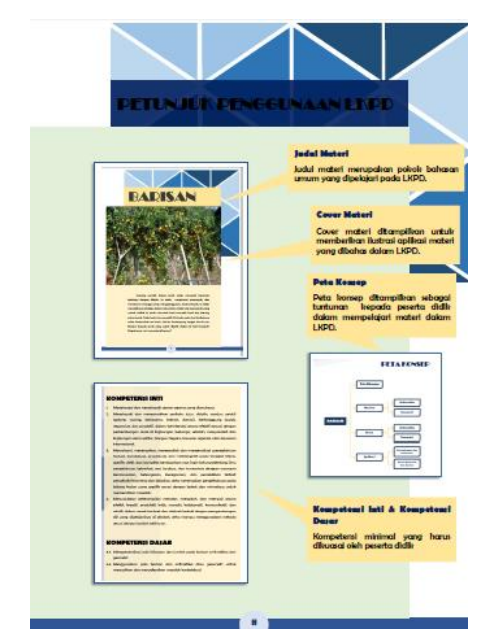

(c) 


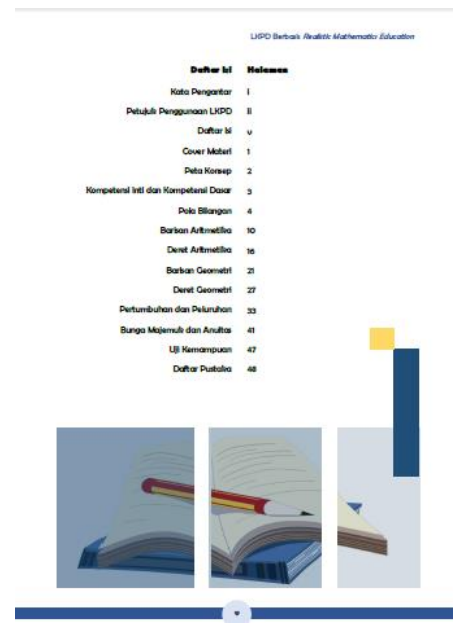

(d)

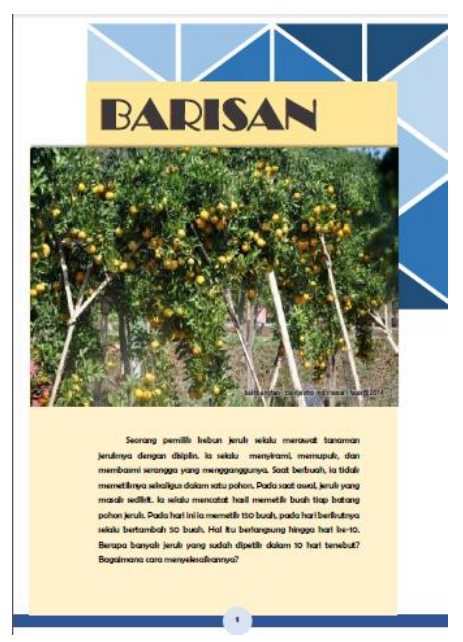

(e)

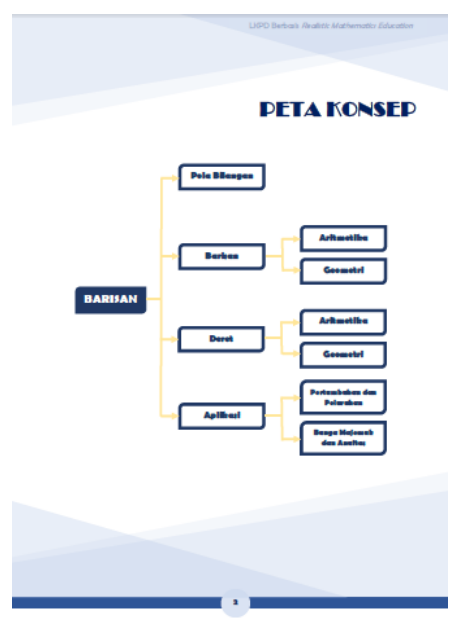

(f) 
Pengembangan Lembar Kerja Peserta Didik Berbasis Realistic Mathematics Education untuk Meningkatkan Kemampuan Argumentasi Peserta Didik, Fera Zulainy, Rusdi, Jefri Marzal

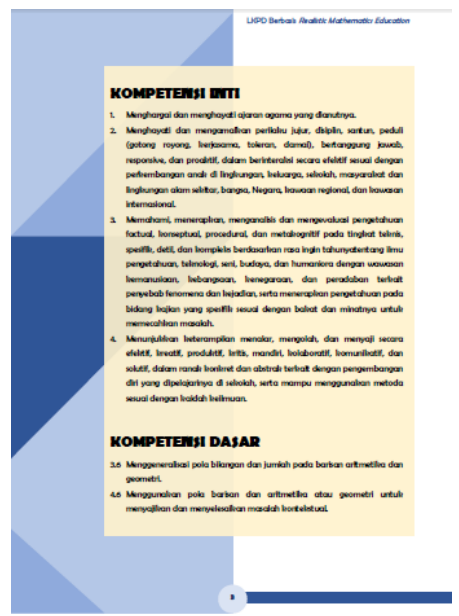

$(\mathrm{g})$

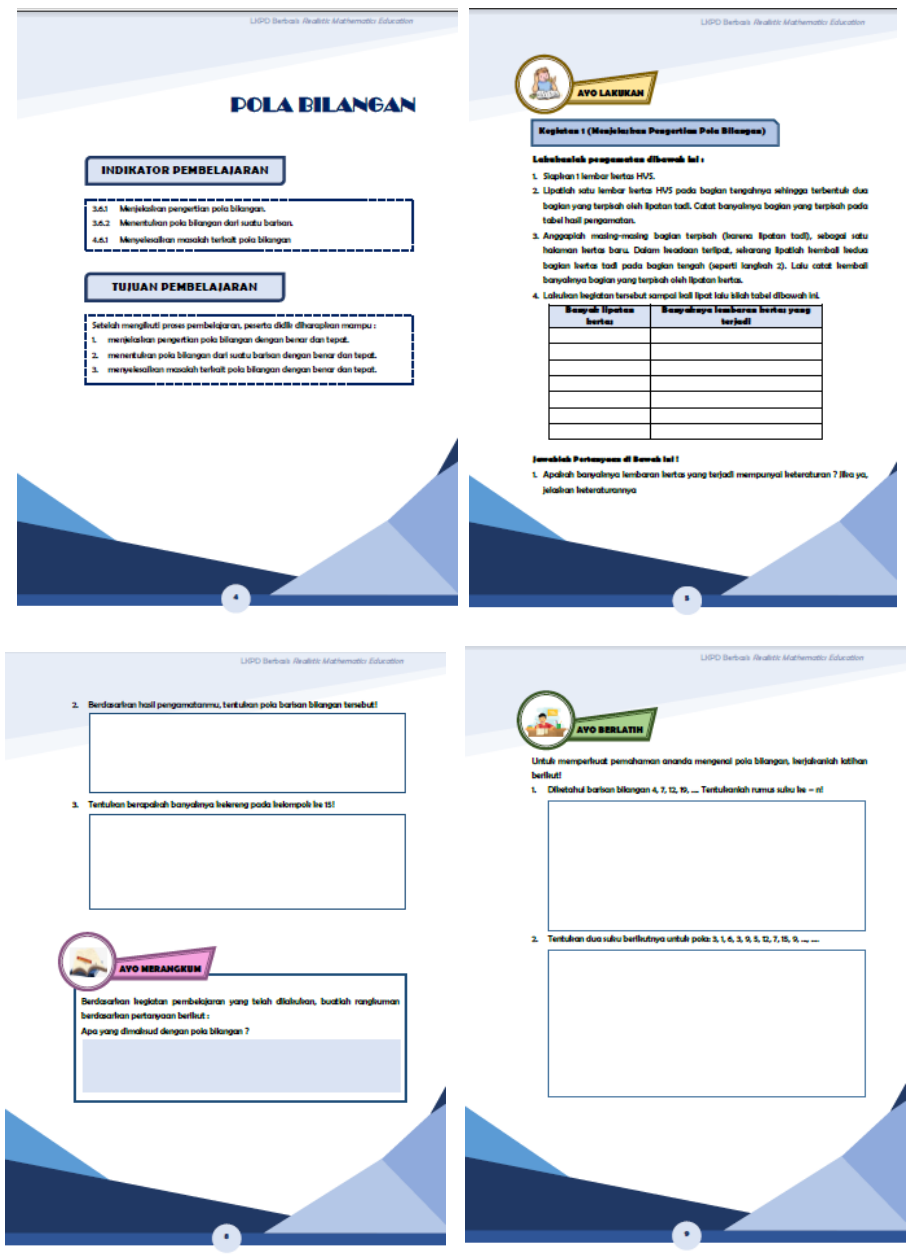

(h) 


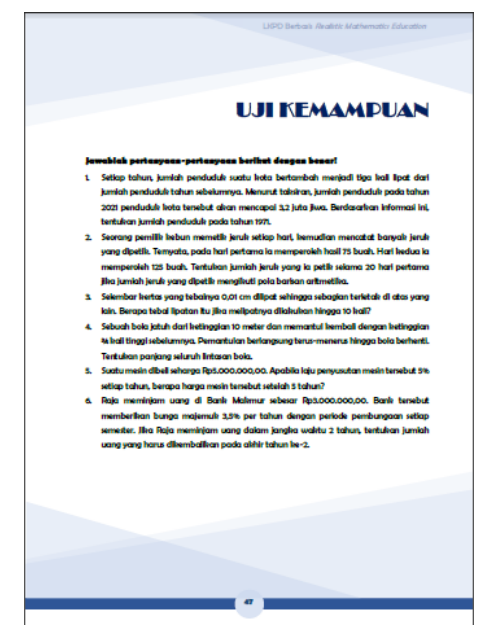

(i)

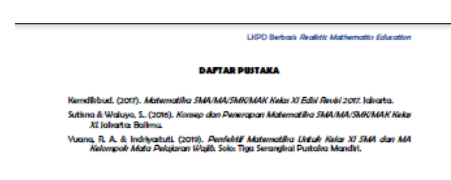

(j)

Gambar 1. Prototipe Awal LKPD; (a) Halaman sampul depan dan belakang; (b) Kata pengantar; (c) Petunjuk penggunaan LKPD; (d) Daftar isi; (e) Cover materi; (f) Peta konsep; (g) Kompetensi inti dan kompetensi dasar; (h) LKPD 1; (i) Uji kemampuan; (j) Daftar Pustaka

\section{Development}

Tahapan selanjutnya setelah mendesain produk adalah development. Prototype produk yang telah dibuat dikembangkan dengan cara penilaian atau validasi dari ahli dan praktisi untuk mendapatkan produk LKPD berbasis realistic mathematics education untuk meningkatkan kemampuan argumentasi peserta didik final. Validasi ahli dilakukan oleh 2 orang dosen program studi magister pendidikan matematika universitas jambi yaitu sebagai validator ahli desain pembelajaran, ahli desain produk dan ahli materi. Validasi praktisi diberikan kepada 2 orang guru matematika pada MAN 1 Batang hari. Validasi dilakukan dengan cara memberikan angket yang terdiri dari beberapa pertanyaan untuk melihat pandangan validator terhadap LKPD yang dikembangkan. Adapun komentar dan saran dari ahli dan praktisi serta keputusan revisi adalah sebagai berikut. 
Tabel 1. Komentar/Saran Dari Validator Serta Keputusan Revisi

\begin{tabular}{|c|c|c|}
\hline Nama Validator & Komentar/Saran & Keputusan Revisi \\
\hline Syaiful & $\begin{array}{l}\text { 1. Setiap materi harus dilengkapi } \\
\text { dengan minimal } 3 \text { soal latihan. } \\
\text { 2. Perlu dibuatkan kunci jawaban } \\
\text { LKPD. } \\
\text { 3. Perlu ditambahkan nomor urut } \\
\text { LKPD disetiap judul materi } \\
\text { misalnya LKPD 1, LKPD 2, dst. }\end{array}$ & $\begin{array}{l}\text { 1. Penambahan soal latihan pada } \\
\text { setiap materi menjadi terdiri dari } \\
3 \text { soal latihan. } \\
\text { 2. Dibuatkan kunci jawaban LKPD. } \\
\text { 3. Penambahan judul berupa nomor } \\
\text { urut LKPD disetiap materi. }\end{array}$ \\
\hline Nizlel Huda & $\begin{array}{l}\text { 1. Memasukkan langkah-langkah } \\
\text { pembelajaran berbasis Realistic } \\
\text { Mathematics Education. } \\
\text { 2. Perbaiki tampilan daftar isi. } \\
\text { 3. Beberapa kalimat tidak sesuai } \\
\text { dengan EYD. }\end{array}$ & $\begin{array}{l}\text { 1. Langkah-langkah pembelajaran } \\
\text { atau Sintaks Realistic } \\
\text { Mathematics Education yang } \\
\text { terdiri dari } 5 \text { langkah } \\
\text { ditambahkan pada setiap kegiatan } \\
\text { dalam LKPD. } \\
\text { 2. Tampilan daftar isi diperbaiki } \\
\text { pada bagian judul materi dengan } \\
\text { memberikan keterangan nomor } \\
\text { urut LKPD. } \\
\text { 3. Kalimat "apakah sama nilai } \\
\text { selisih setiap suku tersebut?" } \\
\text { diganti menjadi "Apakah nilai } \\
\text { selisih setiap suku adalah sama?". }\end{array}$ \\
\hline Nurdin & $\begin{array}{l}\text { 1. Materi yang disajikan sudah } \\
\text { mencerminkan jabaran substansi } \\
\text { materi dalam KD dan sesuai } \\
\text { dengan konsep isi materi Barisan. } \\
\text { 2. Kalimat yang digunakan dalam } \\
\text { LKPD jelas dan mudah dipahami. }\end{array}$ & - \\
\hline Ratih Hadiyati & $\begin{array}{l}\text { 1. Peserta didik dapat mengunakan } \\
\text { LKPD dengan mudah karena } \\
\text { adanya langkah-langkah kegiatan } \\
\text { pembelajaran dalam LKPD. } \\
\text { 2. Kalimat dalam LKPD sudah } \\
\text { sesuai dengan EYD. }\end{array}$ & - \\
\hline
\end{tabular}

\section{Kondisi Kondusif}

Kondisi yang kondusif diperlukan oleh pengembang dalam mendesain dan mengembangkan produk secara efisien karena akan sangat menentukan spesifikasi dan karakteristik dari produk yang dihasilkan. Indikator dalam menentukan kondisi yang kondusif dalam mendesain dan mengembangkan produk secara efisien diantaranya adalah dalam mendesain dan mengembangkan memerlukan lingkungan kerja yang bagaimana, teknologi pendukung yang bagaimana, dan keterampilan dan pengetahuan khusus apa yang harus dimiliki oleh pengembang (Rusdi, 2019).

Dalam mendesain dan mengembangkan Lembar Kerja Peserta Didik berbasis Realistic Mathematics Education, pengembang memiliki lingkungan kerja yang selalu berpikir positif serta 
terbuka terhadap isu-isu kritis dalam pengembangan produk. Hal ini menjadi penting karena lingkungan kerja dalam memproduksi produk akan sangat menentukan kualitas hasil yang diperoleh (Rusdi, 2019).

Pengembangan Lembar Kerja Peserta Didik berbasis Realistic Mathematics Education dibuat dalam Microsoft Word kemudian dipindahkan ke pdf. Penggunaan Microsoft Word dalam mendesain tampilan halaman sampul serta background LKPD cukup merepotkan karena seringnya gambar berpindah-pindah tempat. Akan lebih memudahkan jika pengembang memiliki keterampilan dalam hal desain grafis melalui software lain seperti adobe photoshop. Hal ini menuntut pengembang untuk memiliki keterampilan khusus dalam hal desain grafis.

Dalam mengembangkan LKPD pengembang juga dituntut untuk menguasai konsep dan prosedur dalam desain pembelajaran, penguasaan materi yang baik serta dalam memahami teori beban kognitif. Hal ini menjadi penting agar LKPD yang dikembangkan mempertimbangkan prinsip-prinsip pembelajaran, uraian materi yang tersaji dalam LKPD dapat secara baik menumbuhkan pemahaham dan kejiwaan peserta didik sebagai bagian dari peningkatan keterampilan belajar peserta didik (Rusdi, 2019).

\section{Dampak Potensial}

Dampak potensial diperoleh dari penggunaan teori-teori pada produk yang berpotensi meningkatkan kemampuan argumentasi peserta didik. Lebih lanjut, dampak potensial didapatkan melalui kerangka teori yang menghubungkan antara model realistic mathematics education sebagai penyebab dengan kemampuan argumentasi sebagai akibat. Dengan kata lain, dampak potensial didapat dengan cara melihat kesesuaian antara penggunaan sintaks, karakteristik dan prinsip RME pada LKPD dengan tujuan akhir pembelajaran yaitu meningkatnya kemampuan argumentasi peserta didik.

Lembar kerja peserta didik yang dikembangkan berbasis realistic mathematics education. Ide utama dalam pembelajaran matematika realistik yang juga merupakan salah satu prinsip dalam RME adalah peserta didik harus diberi kesempatan untuk menemukan kembali (reinvention) konsep matematika dengan bimbingan dari guru. Prinsip ini berarti peserta didik diberi kesempatan dalam menemukan sendiri konsep matematika dengan menyelesaikan berbagai soal kontekstual. Lebih lanjut Freudental mengatakan bahwa matematika harus dikaitkan dengan realita dan matematika merupakan aktivitas manusia (Gravemeijer, 1994). Hal ini berarti matematika harus dekat dengan peserta didik serta relevan dengan kehidupan nyata sehari-hari. Kegiatan pembelajaran yang terdapat pada LKPD selalu diawali dengan masalah kontekstual yang relevan dengan kehidupan sehari-hari peserta didik. Hal ini dimaksudkan untuk memfasilitasi meningkatnya kemampuan argumentasi peserta didik. Melalui penyelesaian masalah kontekstual ini, peserta didik akan dapat memunculkan indikator kemampuan argumentasi data, warrant, backing dan claim. Pernyataan ini senada dengan pernyatan yang menyatakan bahwa konsep argumentasi ini sangat tepat digunakan untuk menjelaskan aspek-aspek spesifik dari aktivitas sehari-hari (Aberdein \& Dove, 2013).

LKPD yang dikembangkan merupakan LKPD yang membantu peserta didik dalam menemukan suatu konsep. Hal ini sejalan dengan karakteristik RME terkait pemanfaatan hasil konstruksi peserta didik. Peran peserta didik sebagai subjek belajar dalam RME menuntut peserta didik untuk memberikan 
konstribusi dalam kegiatan belajar, yang meliputi ide, gagasan, maupun argumen tentang konsep matematika. Konstribusi ini berfungsi sebagai jalan dalam mengkonstruksi konsep matematika baik secara mandiri melalui pemecahan masalah maupun dalam bentuk kegiatan lain yang dilakukan oleh peserta didik (Isrok'atun \& Rosmala, 2018). Disini peserta didik memiliki kebebasan dalam menyelesaikan masalah nyata yang diberikan guru serta memiliki kebebasan untuk mengembangkan strategi penyelesaian masalah sehingga diharapkan akan diperoleh berbagai varian dari pemecahan masalah tersebut serta kemampuan argumentasi peserta didik juga meningkat.

Salah satu sintaks dalam pembelajaran berbasis RME adalah mendiskusikan masalah kontekstual. LKPD yang dikembangkan menuntun peserta didik untuk menyelesaikan serta mendiskusikan masalah kontekstual yang diberikan. Melalui kegiatan diskusi ini diharapkan kemampuan argumentasi peserta didik meningkat. Hal ini sesuai dengan hasil penelitian dari yang menyatakan bahwa melalui kegiatan diskusi, peserta didik dapat mengembangkan kemampuan argumentasinya (Pritasari et al., 2016).

\begin{tabular}{|c|c|c|}
\hline $\begin{array}{l}\text { Aspek } \\
\text { RME }\end{array}$ & Indikator & $\begin{array}{l}\text { Kemampuan } \\
\text { Argumentasi }\end{array}$ \\
\hline \multirow[t]{5}{*}{ Sintaks RME } & Memahami masalah kontekstual & \multirow{4}{*}{$\begin{array}{l}\text { Memberikan } \\
\text { data }\end{array}$} \\
\hline & Menjelaskan masalah kontekstual & \\
\hline & Menyelesaikan masalah kontekstual & \\
\hline & Mendiskusikan masalah kontekstual & \\
\hline & Menyimpulkan & \multirow{3}{*}{$\begin{array}{l}\text { Memberikan } \\
\text { claim }\end{array}$} \\
\hline \multirow{5}{*}{$\begin{array}{l}\text { Karakteristik } \\
\text { RME }\end{array}$} & Penggunaan konteks & \\
\hline & $\begin{array}{l}\text { Penggunaan model untuk } \\
\text { memfasilitasi matematika progresif }\end{array}$ & \\
\hline & $\begin{array}{l}\text { Pemanfaatan hasil konstruksi peserta } \\
\text { didik }\end{array}$ & \multirow[t]{3}{*}{$\begin{array}{l}\text { Memberikan } \\
\text { warrant }\end{array}$} \\
\hline & Interaktifitas & \\
\hline & Keterkaitan & \\
\hline \multirow[t]{3}{*}{ Prinsip RME } & Guided reinvention & \multirow{3}{*}{$\begin{array}{l}\text { Memberikan } \\
\text { backing }\end{array}$} \\
\hline & Didactical Phenomenology & \\
\hline & Self developed models & \\
\hline
\end{tabular}

Gambar 2. Peta konsep kesesuaian antara penggunaan RME dalam LKPD dengan kemampuan argumentasi yang diperoleh

Penerapan teori belajar dan pembelajaran serta prinsip Realistic Mathematics Education sudah tertanam dengan baik pada produk dan dinyatakan valid oleh validator. Itu berarti, terdapat relevansi indikator-indikator dari ketiga aspek RME dengan produk LKPD dan kemampuan argumentasi peserta didik sebagai hubungan sebab akibat telah sesuai dengan validasi ahli. Penerapan teori-teori ini memberikan dampak atau implikasi secara logis pada komponen argumentasi sehingga dapat disimpulkan bahwa lembar kerja peserta didik berbasis Realistic Mathematics Education berpotensi meningkatkan kemampuan argumentasi peserta didik.

\section{KESIMPULAN}

Berdasarkan hasil penelitian pengembangan dan pembahasan mengenai pengembangan Lembar Kerja Peserta Didik berbasis Realistic Mathematics Education, maka dapat ditarik kesimpulan sebagai berikut: 
1. Proses yang direkomendasikan dalam mendesain dan mengembangkan LKPD berbasis Realistic Mathematics Education dengan menggunakan model pengembangan ADDIE yang terdiri dari: (1) Analyze yaitu menganalisis kurikulum, karakteristik peserta didik dan lingkungan kerja, (2) Design yaitu menentukan tim pengembang, menyusun jadwal pengembangan, menentukan struktur materi, pembuatan storyboard, menentukan spesifikasi produk, dan membuat prototype produk, dan (3) Development terdiri dari validasi ahli dan praktisi.

2. Kondisi yang kondusif untuk mendesain dan mengembangkan Lembar Kerja Peserta Didik berbasis Realistic Mathematics Education, yaitu: (1) adanya lingkungan kerja yang selalu berpikir positif serta terbuka terhadap isu-isu kritis dalam pengembangan produk; (2) memiliki keterampilan dan pengetahuan khusus dalam hal desain grafis; dan (3) memiliki penguasaan tentang desain pembelajaran, penguasaan materi yang baik serta pemahaman terhadap teori beban kognitif.

3. Dampak potensial didapat dengan cara melihat kesesuaian antara penerapan teori belajar dan pembelajaran serta prinsip Realistic Mathematics Education dengan tujuan akhir pembelajaran yaitu meningkatnya kemampuan argumentasi peserta didik. Penerapan teori belajar dan pembelajaran serta prinsip Realistic Mathematics Education sudah tertanam dengan baik pada produk dan dinyatakan valid oleh validator. Penerapan teori-teori ini memberikan dampak atau implikasi secara logis pada komponen argumentasi sehingga dapat disimpulkan bahwa lembar kerja peserta didik berbasis Realistic Mathematics Education berpotensi meningkatkan kemampuan argumentasi peserta didik.

\section{REFERENSI}

Aberdein, A., \& Dove, I. J. (2013). The argument of mathematics. https://doi.org/10.1007/978-94-007$6534-4$

Acar, O., \& Patton, B. R. (2012). Argumentation and Formal Reasoning Skillsin an ArgumentationBased Guided Inquiry Course. Procedia - Social and Behavioral Sciences, 46, 4756-4760. https://doi.org/10.1016/j.sbspro.2012.06.331

Amielia, S. D., Suciati, S., \& Maridi, M. (2018). Enhancing Students' Argumentation Skill Using an Argument Driven Inquiry-Based Module. Journal of Education and Learning (EduLearn). https://doi.org/10.11591/edulearn.v12i3.8042

Branch, R. M. (2009). Approach, Instructional Design: The ADDIE. In Department of Educational Psychology and Instructional Technology University of Georgia (Vol. 53, Issue 9).

Brinkerhoff, J. A. (2007). Applying toulmin's argumentation framework to explanations in a reformoriented mathematics class (Issue August).

Bunga, N., Isrok'atun, \& Julia. (2017). Pendekatan Realistic Mathematics Education Untuk Meningkatkan Kemampuan Generalisasi Matematis Siswa. Jurnal Penelitian Dan Pembelajaran Matematika, 10(2), 441-450. https://doi.org/10.30870/jppm.v10i2.2043

Dawson, V. M., \& Venville, G. (2010). Teaching strategies for developing students' argumentation 
skills about socioscientific issues in high school genetics. Research in Science Education, 40(2), 133-148. https://doi.org/10.1007/s11165-008-9104-y

Deane, P., \& Song, Y. (2014). A case study in principled assessment design: Designing assessments to measure and support the development of argumentative reading and writing skills. Psicologia Educativa, 20(2), 99-108. https://doi.org/10.1016/j.pse.2014.10.001

Depdiknas. (2008). Panduan Pengembangan Bahan Ajar. In Depdiknas Jakarta. http://file.upi.edu/Direktori/FIP/JUR._KURIKULUM_DAN_TEK._PENDIDIKAN/1946012919 81012-PERMASIH/PENGEMBANGAN_BAHAN_AJAR.pdf

Dick, W., \& Carey, L. (2015). The systematic design of instruction. 6th. In Boston, MA. Pearson.

Eemeren, F. H., Garssen, B., Krabbe, E. C. W., Snoeck Henkemans, A. F., Verheij, B., \& Wagemans, J. H. M. (2014). Handbook of argumentation theory. In Handbook of Argumentation Theory. Springer. https://doi.org/10.1007/978-90-481-9473-5

Ginanjar, W. S., Utari, S., \& Muslim. (2015). Penerapan Model Argument-Driven Inquiry Dalam Pembelajaran Ipa Untuk Meningkatkan Kemampuan Argumentasi Ilmiah Siswa Smp. Jurnal Pengajaran Matematika Dan Ilmu Pengetahuan Alam, 20(1), 32. https://doi.org/10.18269/jpmipa.v20i1.559

Gravemeijer, K. P. E. (1994). Developing Realistic Mathematics Education: Ontwikkelen Van Realistisch Reken/wiskundeonderwijs., 1994. In CD-[beta] Press. CD Press.

Hendri, S., \& Defianti, A. (2015). Review : Membentuk Keterampilan Argumentasi Siswa Melalui Isu Sosial Ilmiah dalam Pembelajaran Sains (Vol. 2015, Issue Snips).

Isrok'atun, \& Rosmala, A. (2018). Model-Model Pembelajaran Matematika. Bumi Aksara.

KBBI. (2020). Kamus Besar Bahasa Indonesia (KBBI) Kamus versi online/daring. Kemendikbud.

Kemendikbud. (2016). Permendikbud Nomor 21 Tahun 2016 Tentang Standar Isi Pendidikan Dasar dan Menengah (Issue August).

Laamena, C. (2017). Karakteristik Warrant Dalam Argumentasi dan Pembuktian Matematis. Penegakan Hak Asasi; Forum Anak; Daya Saing Bangsa, 34(46), 661-670. https://semnas.unikama.ac.id/lppm/prosiding/2017/2.PANGAN $\&$ TERNAK/Dyah_Nurul_A_Penelitian_Pangan_Ternak.pdf

Majid, A. (n.d.). Strategi Pembelajaran. Rosda.

Ningsih, S. (2014). Realistic Mathematics Education: Model Alternatif Pembelajaran Matematika Sekolah. Jurnal Pendidikan Matematika, 1(2), 73. https://doi.org/10.18592/jpm.v1i2.97

Prastowo, A. (2015). Panduan Kreatif Membuat Bahan Ajar Inovatif. Diva Press.

Pritasari, A. C., Dwiastuti, S., \& Probosari, R. M. (2016). Peningkatan Kemampuan Argumentasi melalui Penerapan Model Problem Based Learning pada Siswa Kelas X MIA 1 SMA Batik 2 Surakarta Tahun Pelajaran 2014/201. Jurnal Pendidikan Biologi, 8(1), 1-7.

Rusdi, M. (2019). Penelitian Desain dan Pengembangan Kependidikan(Konsep, Prosedur dan Sintesis Pengetahuan Baru). Rajawali Press. 
Umah, U., Asari, A. R., \& Sulandra, I. M. (2016). Struktur Argumentasi Penalaran Konvasional Siswa Kelas VIII B MTsN 1 Kediri. JMPM: Jurnal Matematika Dan Pendidikan Matematika. https://doi.org/10.26594/jmpm.v1i1.498

Wijaya, A. (2012). Pendidikan matematika realistik: suatu alternatif pendekatan pembelajaran matematika. In Yogyakarta : Graha Ilmu. 